\title{
Smallest eukaryotic organism
}

SIR - Autotrophic communities of picoplankton (cell size less than $2 \mu \mathrm{m}$ diameter), known to be dominated by prokaryotes $^{1}$, are essential in the carbon cycle of estuaries ${ }^{2}$ and oceans ${ }^{1,3}$. Hall and Vincent report that in other nutrient-rich ecosystems, the eukaryotic forms of the picoplankton "can play a major role in generating new production"4. That seems to be the case for the marine Mediterranean Thau lagoon (France, $43^{\circ} 24^{\prime} \mathrm{N}-3^{\circ} 36^{\prime}$ E) where, using flow cytometry, we have discovered a photosynthetic picoeukaryote which is the main component of the phytoplankton. This picoplankter is

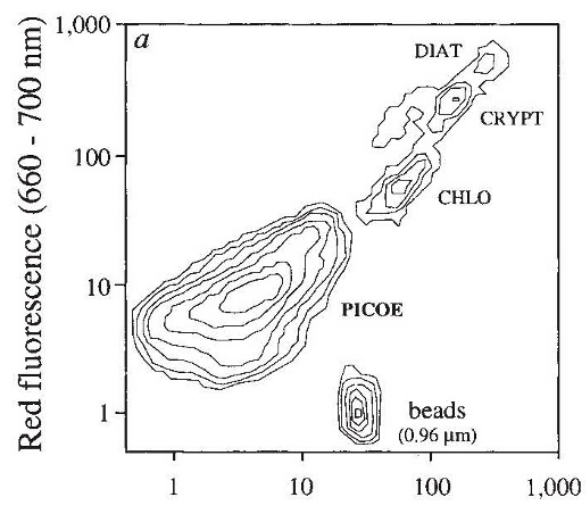

Forward angle light scatter

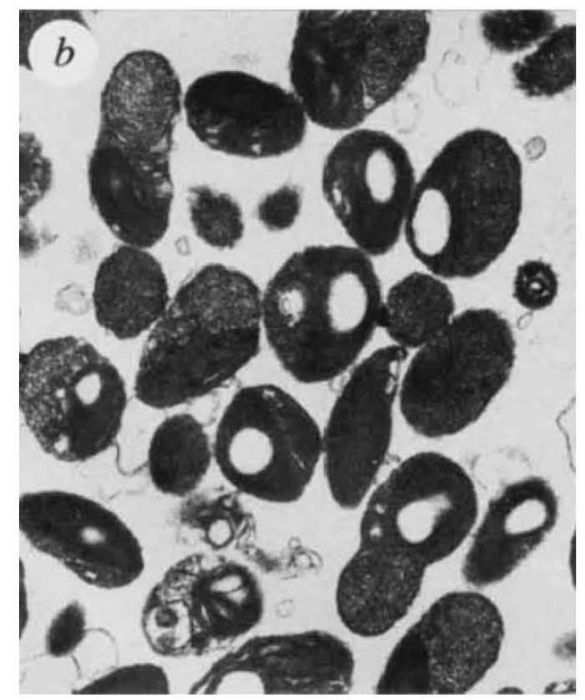

a, Flow-cytometric measurement of the phytoplanktonic assemblage in Thau lagoon. Phytoplanktonic cells were distinguished according to their forward-angle light scatter ( $x$-axis) and red fluorescence ( $y$-axis). They were calibrated using an internal standard (0.96- $\mu \mathrm{m}$ fluorescent beads). The numbers of the new picoeukaryote (PICOE), 0. tauri, dominate the phytoplankton community which otherwise consists of diatoms (DIAT), chlorophytes (CHLO) or cryptophytes (CRYPT) . b. Transverse section $(\times 15,000)$ of several single $O$. tauri cells. Cells generaliy contain no cell wall, a nucleus, one plastid with a starch granule, a very reduced cytoplasmic compartment with one mitochondrion and one Golgi apparatus. classified as a green alga and named Ostreococcus tauri gen. et sp. nov. (C.C. and M.J.C.-D., manuscript submitted).

$O$. tauri, barely visible by epifluorescence microscopy, is detected by flow cytometry as shown in the figure $(a)$, using low-forward-angle light scatter (related to cell size) and low red fluorescence (660$700 \mathrm{~nm}$ ) due to their chlorophyll content. Electron microscopy reveals their extremely simple ultrastructure as detailed in $b$. The mean cell length and width are $0.97 \pm 0.28$ and $0.70 \pm 0.17 \mu \mathrm{m}$, respectively, and the DNA content per cell is $33.31 \pm 2.13 \mathrm{fg}$. O. tauri is thus the smallest eukaryote yet described.

Pigments are characterized by the presence of the three $a-, b$ - and $c$-like chlorophylls, with a $b / a$ ratio of 0.9 and $c / a$ ratio near 0.1 . The $c$-like chlorophyll was identified as the pigment $\mathrm{Mg} 3,8$ divinylpheoporphyrin $\mathrm{a}_{5}$ which is common to some photosynthetic eukaryotes (Prasinophyceae ${ }^{5}$ and prokaryotes (Prochlorococcus marinus $^{6}$ ). Carotenoids are those of Chlorophyceae, with an unusually high violaxanthin content $(3.05 \mathrm{fg}$ per cell). $O$. tauri, counted bimonthly over one year, always appears as the main component of the phytoplankton in the lagoon. Cell abundances range between $10^{7}$ and $2 \times 10^{8}$ cells per litre, which corresponds over the year to an average of 86 per cent of total phytoplankton cells. They are one or two orders of magnitude more abundant in Thau waters than picoeukaryote abundances reported by Hall and Vincent ${ }^{4}$ in upwelling areas. The annual average chlorophyll $a$ biomass related to $O$. tauri is $0.51 \mu \mathrm{g} \mathrm{\textrm {I } ^ { - 1 }}$, which accounts for 28 per cent of the total biomass. In summer, when $O$. tauri is most abundant, carbon assimilation varies from 3.8 to $21.0 \mathrm{mg} \mathrm{C} \mathrm{mg}(\mathrm{Chl} a)^{-1}$ $\mathrm{h}^{-1}$. These rates are 1.3-5.4 times higher than those related to larger cells (over 2 $\mu \mathrm{m}$ diameter).

Such consistently high abundance and production raise several questions regarding the trophodynamic role of $O$. tauri. Why does this picoeukaryote species dominate the phytoplankton in the Thau lagoon? In upwelling areas ${ }^{4}$, or in dystrophic and acidic lakes ${ }^{7}$, the cold temperature and nitrate-enriched conditions, or low $\mathrm{pH}$, might respectively explain picoeukaryote dominance. These factors are not relevant in temperate marine waters where the $\mathrm{pH}$ is stable at around 8.2 . One reason for the adaptation and high production of $O$. tauri in Thau waters could be its unusual amount of violaxanthin pigment, which acts as a photoprotectant $^{8}$. In the Thau lagoon, irradiance frequently reaches $2,000 \mu \mathrm{E}$ $\mathrm{m}^{-2} \mathrm{~s}^{-1}$ at the subsurface water layer, and the transmitted light at a depth of $4.5 \mathrm{~m}$ is always more than 10 per cent of the incident radiation. Another hypothesis is related to the intensive oyster culture in the lagoon $(25,000$ tons produced per year). The oysters excrete large amounts of ammonium ion (1.04 $\mathrm{umol}$ in the oyster beds and $0.35 \mu \mathrm{mol}$ outside), which favours picoplankton over the larger size classes 9 . Also, oysters preferentially retain large cells ${ }^{10}$ more than $2 \mu \mathrm{m}$ in diameter, which could encourage the development of the cells smaller than $1 \mu \mathrm{m}$.

We are now examining how common this alga is, to discover whether these organisms represent a substantial but overlooked contribution to primary production in marine coastal waters.

\section{Claude Courties}

André Vaquer

Marc Troussellier

Jacques Lautier

Laboratoire d'Hydrobiologie Marine,

Université Montpellier II.

URA CNRS 1355, URM n 5 ,

CC 093, 34095 Montpellier Cedex 5.

France

Marie J. Chrétiennot-Dinet

Jacques Neveux

Cordelia Machado

Observatoire Océanologique de Banyuls,

URA 117, Laboratoire Arago,

66650 Banyuls-sur-Mer, France

Hervé Claustre

Laboratoire de Physique et Chimie Marines, La Darse, BP 8 ,

06230 Villefranche-sur-Mer, France

\footnotetext{
1. Stockner. J. G. \& Antia, N. J. Can. J. Fish. Aquat. Sci. 43. 2472-2503 (1986)

2. Malone, T. C., Ducklow, H. W., Peele, E. R. \& Pike, S. E. Mar. Ecol. Prog. Ser. 78, 11-22 (1991)

3. Platt, T. \& Li, W. K. W. (eds) Photosynthetic Picoplankton (Ottawa) Can. Bull. Fish. Aquat. Sci 214 (1986)

4. Hall, J. A. \& Vincent. W. F. Mar. Biol. 106. 465-471 (1990).

5. Ricketts, T. R. Phytochemistry 5, 223-229 (1966)

6. Goericke, R. \& Repeta, D. J. Limnol. Oceanogr. 37, 425-433(1992)

7. Stockner, J. G. \& Shortreed, K. S. Revue ges. Hydrobiol. 76. 581-601 (1991).

8. Lawlor, D. W. in Photosynthesis (ed. Lawlor, D. W.) 31-51 (Longman, Harlow, 1993)

9. Chishotm. S. W. in Primary Production and

Biogeochemical Cycles in the Sea (eds Falkowski, P. G. \& Woodhead, A. D.) 213-237 (Plenum, New York, 1992).

10. Destous-Paoli, J. M. in Aquacuiture, Shellfish Culture Development and Management 319-346 (Ifremer. Paris, 1987)
}

\section{Genetic dyet?}

SIR - FISH (fluorescent in situ hybridization) has become a favourite ingredient in cytogenetic recipes. Considering the recent development in early fetal chromosome analysis, the time seems ripe to suggest that FISH \& CHIPS (chromosome interphase staining) should be added to the menu.

\section{Søren Nørby}

Department of Forensic Genetics,

University of Copenhagen,

DK-2100 Copenhagen,

Denmark 